\title{
Ойратский сборник примет «Burxan baqšiyin nom xara šidi orošiboi» как образец буддийской обрядовой литературы
}

\author{
Саглара Викторовна Мирзаева ${ }^{1}$, Бямбажав Тувшинтугс ${ }^{2}$
}

${ }^{1}$ Калмыцкий научный центр РАН (д. 8, ул. им. И. К. Илишкина, 358000 Элиста, Российская Федерация)

научный сотрудник

iD 0000-0002-8542-0260. E-mail: kundgabo@list.ru

\footnotetext{
${ }^{2}$ Монгольский государственный университет (п/я 377, 1, просп. Молодежный, район Сухбаатар, 210646 Улан-Батор, Монголия)

кандидат филологических наук, заведующий кафедрой монгольского языка и языкознания

iD 0000-0002-1447-8924. E-mail: btuvshintugs@num.edu.mn
}

(C) КалмНЦ РАН, 2020

(C) Мирзаева С. В., Тувшинтугс Б., 2020

Аннотация. Цель данной статьи - введение в научный оборот ойратской рукописи «Burxan baqšiyin nom xara šidi orošiboi», название которой условно переведено нами как «Мирская магия учения Будды». Текст хранится в монастыре Рашичойлинг (Баян-Улгийский аймак, Монголия) и доступен в цифровой коллекции ойратских текстов фонда «Тод номын гэрэл». Монгольские списки обнаруживаются в коллекциях монастыря Олон-сюмэ и местности Харбухын Балгас, датируемых началом XVII в. По содержанию текст представляет собой оформленный как буддийское сочинение сборник неблагоприятных примет, перечисление которых сопровождается просьбой устранить их и магическими формулами-дхарани. Просьба, вероятно, обращена к Ваджрадхаре / Ваджрапани, который упоминается в начале текста. Упоминаемые в рукописи приметы, связанные с поведением животных, птиц и людей, продолжают свое бытование в культуре монгольских народов. К неблагоприятным знакам причисляются также природные явления (молния, гром, ураган), плохие помыслы, злословие окружающих, неблагоприятствования харш, связанные с временем, пространством, планетами и звездами, вредоносные влияния различных демонических существ и различные болезни. Интерес представляет описание ритуала, вероятно, сопровождавшего чтение текста, с использованием рога черной коровы и отреза черного сукна. Этот ритуал можно отнести к «черным» ритуалам народной религии, основное назначение которых заключалось в подавлении вредоносных влияний, и вся используемая атрибутика должна была быть черного цвета. Изучение подобных обрядовых текстов позволит в дальнейшем расширить наши знания по мантическим практикам и верованиям монгольских народов и определить роль тибетской традиции в формировании корпуса этих текстов. В приложении приводятся транслитерация и перевод рукописи. 
Ключевые слова: «Мирская магия учения Будды», ойратская рукопись, сборник примет, Ваджрадхара, неблагоприятные предзнаменования

Благодарность. Статья подготовлена по проекту «От палеогенетики до культурной антропологии: комплексное интердисциплинарное исследование традиций народов трансграничных регионов: миграции, межкультурное взаимодействие и картина мира» при поддержке мегагранта Правительства РФ (Соглашение о предоставлении из федерального бюджета грантов в форме субсидий в соответствии с пунктом 4 статьи 78.1 Бюджетного кодекса Российской Федерации № 075-15-2019-1879 от 3 декабря 2019 г.) Для цитирования: Мирзаева С. В., Тувшинтугс Б. Ойратский сборник примет «Burxan baqšiyin nom xara šidi orošiboi» как образец буддийской обрядовой литературы // Монголоведение. 2020. № 1. С. 37-54. DOI: 10.22162/2500-1523-2020-1-37-54.

UDC 821.512 .37

\title{
Burxan baqšiyin nom xara šidi orošiboi: Oirat Collection of Bad Omens as an Example of Buddhist Ritual Text
}

\author{
Saglara V. Mirzaeva1 , Byambajavyn Tuvshintugs ${ }^{2}$ \\ ${ }^{1}$ Kalmyk Scientific Center of the RAS (8, Ilishkin St., Elista 358000, Russian Federation) \\ Research Associate \\ (iD) 0000-0002-8542-0260. E-mail: kundgabo@list.ru
}

${ }^{2}$ National University of Mongolia (mailbox no. 377, 1, Zaluuchudyn Ave., Sukhbaatar District, 210646
Ulaanbaatar, Mongolia)

Ph.D. (Linguistics), Head of Department of Mongolian Language and Linguistics

iD 0000-0002-1447-8924. E-mail: btuvshintugs@num.edu.mn

\author{
(C) KalmSC RAS, 2020 \\ (C) Mirzaeva S. V., Tuvshintugs B., 2020
}

\begin{abstract}
Goals. The article introduces an Oirat manuscript entitled Burxan baqšiyin nom xara šidi orošiboi which can be loosely translated as 'Ordinary Magic of Buddha's Teaching'. The manuscript kept at Rashchoilin Monastery of Bayan-Ölgii Aimag (Mongolia) is available on the online collection of Oirat texts created by Tod Nomyn Gerel Foundation. Mongolian copies of this text can be found in Olon Sume and Xarbuxyn Balgas collections dating back to early $17^{\text {th }}$ century. This manuscript contains a list of unfavorable omens, each of them accompanied with a request to eliminate them (probably, addressed to Vajradhara / Vajrapanni who is mentioned in the beginning of the text) and respective magical dhārañi spells. The bad omens listed in the text are related to animal, bird and human behavior patterns, remaining typical even for contemporary Mongolic cultures. Natural disasters (lightning, thunder, hurricane), bad thoughts, curses, xarsi unfavourables associated with different categories of time, space, planets and stars, harming influence of various demonic creatures and various diseases are also considered unfavorable omens. The ritual described in the text (which may have accompanied the reciting of the text) during which one uses a black cow's horn and a piece of black cloth seems interesting enough. It can be attributed to the 'black' rituals of folk Mongolian religion, the latter primarily aimed to suppress harmful influences through the use of attributes black in color only. Studies of such ritual texts will make it possible to extend our knowledge of the mantic practices and beliefs of Mongolic peoples, thus defining the role of Tibetan tradition in the formation of the corpus of these texts. The appendix to the paper transliterates and translates the manuscript mentioned.

Keywords: Ordinary Magic of Buddha's Teaching, Oirat manuscript, collection of omens, Vajradhara, unfavorable omens

Acknowledgments: The reported study was granted by the Government of the Russian Federation project name 'From Paleogenetics to Cultural Anthropology: Comprehensive Interdisciplinary Studies in Traditions of Cross-Border Regions - Migrations, Intercultural Communication, and Worldviews'
\end{abstract}


(Agreement on Granting Federal Budgetary Subsidies in Accordance with Item 4, Article 78 of the Budget Code of the Russian Federation No. 075-15-2019-1879 of 3 December 2019).

For citation: Mirzaeva S. V., Tuvshintugs B. Burxan baqšiyin nom xara šidi orošiboi: Oirat Collection of Bad Omens as an Example of Buddhist Ritual Text. Mongolian Studies. 2020. No. 1. Pp. 37-54. DOI: $10.22162 / 2500-1523-2020-1-37-54$.

\section{Введение}

В серии публикаций в рамках проекта «От палеогенетики до культурной антропологии...» мы планируем ввести в научный оборот некоторые памятники ойратского «ясного» письма, относящиеся к обрядовой литературе, в которых получили отражение аспекты традиционного мировоззрения монгольских народов. Учитывая тесную связь монголоязычной письменной традиции с тибетской литературой, интересным представляется и привлечение в ходе анализа тибетских текстов.

Цель данной статьи - введение в научный оборот ойратской рукописи «Burxan baqšiyin nom xara šidi orošiboi», название которой условно переведено нами как «Мирская магия учения Будды», из цифровой коллекции ойратских текстов фонда «Тод номын гэрэл» [XS 2011]. Размеры рукописи не приводятся, указано лишь место хранения - монастырь Рашичойлинг в Баян-Улгийском аймаке. Рукопись состоит из одиннадцати листов, пагинация обозначена тибетскими цифрами и соответствующими им числительными (xoyor, yurban, dörbön и т. д.). На титульном листе слева от названия текста синей ручкой приписано «Xutuqtu Očiro padara nomariqson [=nomxariqson] yeke xara šiddha orosiboi» ('Великая мирская (букв. 'черная') магия, усмиряющая [с помощью дхарани] благородного Ваджрадхары’). Текст написан черными чернилами ${ }^{1}$ на желтой бумаге, листы по краям оборваны.

\section{Основная часть}

Монгольские версии этого сочинения обнаруживаются среди рукописей монастыря Олон-сюмэ и местности Харбухын Балгас, которые датируются началом XVII в. Их присутствие в этих коллекциях говорит о том, что сочинение было распространено как на севере, так и на юге Монголии начиная c XVI-XVII вв. Все тексты сохранились в фрагментарном виде и не имеют названий: В. Хайссиг условно называет их «Молитвой-заклинанием Ваджрадхары» (нем. Banngebet an Vajradhara), поскольку молитва обращена к этому божеству [Heissig 1976: 427]; Э. Чиодо указывает два ойратских текста «Хaтuq xara yai xariuluqči sudur» ('Сутра, отвращающая все черные бедствия') и «Yeke xara šidada〉 ('Наделенная великой мирской магией') как наиболее близкие по содержанию к рассматриваемым ею текстам из коллекции Харбухын Балгас [Chiodo 2009: 181]. Из других сборников примет на классическом монгольском

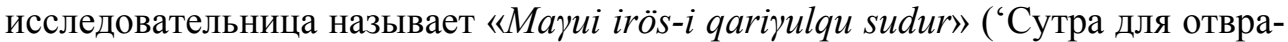

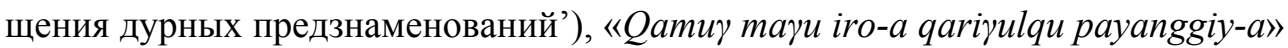
('[Сутра] Паянг-гия² для отвращения всех дурных предзнаменований’), «Eldeb iro-a sinjilel» ('Анализ различных предзнаменований'), «Aliba maүu iro-a-yin üjelge» ('Рассмотрение всех дурных предзнаменований'), «Maүu iro-yin sudur» ('Сутра о плохих предзнаменованиях') [Chiodo 2009: 181].

\footnotetext{
${ }^{1}$ На л. 1b имеются приписки, выполненные синей ручкой.

${ }^{2}$ Возможно, «Баян-цзин», или «Сутра о восьми светоносных» (монг. naiman gegen).
} 


\section{Монголоведение • Mongolian Studies • $2020 \bullet$ T. 12 • №1}

Исследователи отмечают, что повторяющийся в текстах лейтмотив «Mои

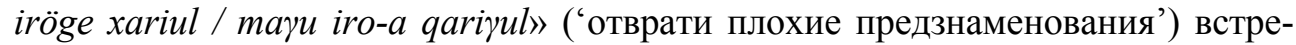
чается также в сочинениях «Öljei qutuүtu tarni» ('Святая дхарани, [дарующая]

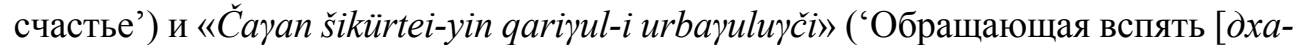
рани] Белозонтичной Тары') ${ }^{3}$ [Heissig 1976: 434; Chiodo 2009: 181], что может свидетельствовать о принадлежности рассматриваемого текста к жанру дхарани. Интересно отметить, что дхарани Белозонтичной Тары в современной буддийской традиции Монголии начитывается в ритуалах, нейтрализующих негативные влияния, в том числе и неблагих предзнаменований [Chiodo 2009: 155].

Текст начинается с санскритской формулы поклонения Трем Драгоценностям (Будде, Дхарме и Сангхе), после которой идет та же формула на ойратском языке, но содержащая дополнительные компоненты поклонения Учителю и всем буддам и бодхисаттвам. Каждый компонент молитвенной формулы, обращенный к одной из Драгоценностей, сопровождается дополнительной фразой «Пусть злые духи будут подавлены [силой] истинного слова ...» (ойр. ... ünen zarliq-yēr čidküri darutuүai). Затем выражается почтение и воздается хвала бодхисаттве Ваджрапани как владыке тайных учений. Далее в тексте он называется Ваджрадхарой, дхарани которого способно нейтрализовать все неблагие предзнаменования.

В основной части текста начинается перечисление неблагоприятных знаков, бедствий, связанных с различными категориями времени и пространства, и болезней, сопровождаемое просьбами «отвратить», или нейтрализовать, их. Начиная с л. 5а, просьбы перемежаются заклинаниями-дхарани, произнесение которых, очевидно, призвано усилить эффект ритуала.

Большая часть неблагоприятных примет основана на поведении животных. Назовем некоторые из них:

- олени дерутся на вериины горы;

- собаки лают и пытаются забраться на крышу;

- лисица скулит и лает в дневное время;

- филин летит днем и издает звуки, напоминающие смех;

- мерин находится среди кобылиц;

- кони в стаде ржут, отворачиваясь друг от друга;

- у коровы случается выкидыли;

- вороны каркают и дерутся в небе;

- сова ухает над домами;

- змея лежит на земле, обратившись в сторону дома;

- собака лежит на земле, повернувшись спиной;

- корова ложится после того, как копытами взрыхлит землю;

- улошади идет носом кровь.

Несколько примет основаны на поведении людей: плохим предзнаменованием считаются спорящие женщины, которые стоят между двумя домами; шаманы и шаманки в общем, а также шаманы, проводящие, вероятно, какой-то обряд с использованием многоцветного шнура (веревки) и ковыля; буддийские священнослужители, у которых во время проведения молебна голос становит-

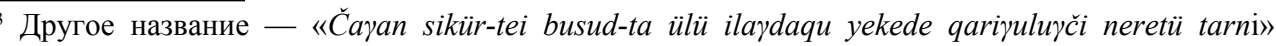
('Дхарани Белозонтичной Тары, которую не могут одолеть другие, под названием «Великая обращающая вспять [негативное влияние]»').
} 
ся неблагозвучным, и пр. Стоит отметить, что в тексте к неблагим предзнаменованиям относятся также недоброжелательные помыслы (ойр. mou sanaqsan) родственников и окружающих людей. Интересной представляется примета о том, что период солнечного затмения опасен для ханши, а лунного - для хана, в которой можно усмотреть реликты соотнесенности дихотомии «солнце-луна» с женским и мужским началом. Так, Э. П. Бакаева предполагает, что в культуре монгольских народов «солярное божество-покровитель <...> до образа предка по отцовской линии представлял собой предка по материнской линии» [Бакаева 2009: 66].

К плохим знакам в сочинении «Burxan baqšiyin nom xara šidi orošiboi» относятся природные явления - ураган, молния, гром, и встречи с дикими животными - тиграми, змеями и т. д., а также препятствия харш, связанные с разными временными (год, месяц, день, ночь и т. д.) и пространственными (четыре основных и четыре промежуточных направления) категориями, планетами и звездами. Описываемый У. Душаном аналогичный концепт $x_{a p a w}^{4}$ в калмыцкой культуре связан в первую очередь с астрологией и несоответствием годов рождения, исправление которого важно перед заключением брака [Душан 2016: 144-148]. Хараш воспринимался калмыками очень серьезно, и встречались случаи, когда его невозможно было исправить (калм. иусн харш 'несоответствие по крови'), которые часто заканчивались смертью одного из супругов [Душан 2016: 146-147].

Одна из разновидностей харш, описываемая в тексте, связана с возрастом (ойр. nasuni rai xarši). Согласно буддийскому обряду, исправления мэнгэ (монг. мэнгэ засал) ${ }^{5}$, направленному на устранение астрологических несоответствий хари, необходимость проведения обряда возникает каждые девять лет жизни, а также в двадцать первый, двадцать восьмой, тридцатый и тридцать шестой годы шестидесятилетнего цикла [Позднеев 1993: 426, 431]. Однако в рассматриваемом сочинении представлена другая классификация, согласно которой опасность харш возникает каждые десять лет: arban nasuni yai xarši 'бедствие десятилетнего возраста', $20^{6}$ nasuni yai xarši 'бедствие двадцатилетнего возраста’, 30 nasuni yai xarš $i$ ‘бедствие тридцатилетнего возраста’ и т. д.

В число просьб об избавлении от различных бед входят пожелания, чтобы злословие (ойр. kelen aman) других людей (с указанием количества людей от одного до десяти) не имело негативного эффекта на адресата, что, возможно, семантически связано с обрядом «отрезания черного языка», популярным в тибето-монгольской буддийской традиции.

Затем в тексте начинаются просьбы о защите от различных духов и классов существ, причем перечисляются представители и буддийского пантеона - acy-

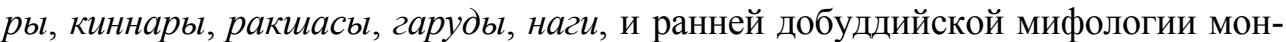
гольских народов - албиныл, духи элээ, кулчины, чутгуры и иимнусы ${ }^{7}$. В представленной классификации последних интерес представляет их цветовая мар-

\footnotetext{
${ }^{4}$ Так в трудах У. Душана.

${ }^{5}$ О понятии «мэнгэ» см. подробнее: [Митруев 2019: 510].

6 Здесь и далее: в тех случаях, когда в транслитерации числительное обозначается римской цифрой, в ойратском тексте оно обозначено тибетской цифрой.

${ }^{7}$ Помимо перечисленных, в тексте встречается слово $a d a$, первое значение которого - «класс демонических существ», однако в данном тексте мы переводим его во втором значении «вредоносное влияние».
} 


\section{Монголоведение • Mongolian Studies • $2020 \bullet$ T. 12 • №1}

кировка и локативный код: красные албины и чутгуры соотносятся с северной стороной, духи элээ - с восточной, пять чутгуров - с югом и шимнусы (принимающие облик коров?) - с западом. Далее духи элээ разделяются также в соответствии с вертикальным делением мира на три сферы: к небу относятся белые элээ, к промежуточному пространству - пестрые, к третьему уровню, называемому в тексте воздухом (ойр. our), — плохие элээ без указания цвета.

Как правило, в словарных статьях, посвященных названиям этих демонических персонажей, приводится значение «злой дух, демон» без указания их специфики [МРФС 1844-1849: 84, 206, 1505, 2159, $2607^{8}$ ].

Д. Банзаров в своей работе «Черная вера, или шаманство, у монголов» приводит описание некоторых из этих существ: духи элээ описываются им как принимающие облик птиц ${ }^{9}$ и предвещающие несчастье, кулчины - безобразные духи, являющиеся в виде привидений, чтобы испугать человека, албины любят обманывать людей, бродя около дорог и сбивая с пути [Банзаров 1891: 30].

Ч. Боудэн определяет элээ и кулчинов как духов, которые могут спровоцировать болезнь или смерть ${ }^{10}$ [Bawden 1961: 244]. Что касается их происхождения, исследователь пишет, что ими становятся души некоторых людей после смерти [Bawden 1961: 244, 247]. Эти духи, несомненно, относятся к автохтонной мифологии монгольских народов, однако их наименования также использовались для перевода с тибетского языка слов, обозначающих существ тибетского бестиария: монг. eliy-e - перевод тиб. 'gong ро 'демон гонгnо, насылающий болезнь', монг. albin - перевод тиб. btsan 'воинственный демон иээ', simnus - перевод тиб. bdud 'Мара, демон'.

Отдельного рассмотрения в статье требует перевод и интерпретация названия сочинения, а именно термина xara sidi ('мирская (букв. черная) магия'), включенного в него. Традиционно в монголоведении «черной верой» (qara/ xara šasin) называют шаманизм как воззрение, противопоставляющееся «желтой вере» (sira šasin) школы гелуг тибетского буддизма. «Черная вера», или «черная сторона» ${ }^{11}$ (qara jüg / xara züq), — это термин, использовавшийся тибетскими буддистами с целью принизить оппонентов, причем впоследствии он был принят шаманистами в качестве самоназвания [Kollmar-Paulenz 2012: 100].

Другим термином для обозначения шаманизма, часто встречающимся в сочинениях XVII-XIX вв., а также в рассматриваемом тексте, является сочетание монг. buruүu ӥјеl / ойр. buruи üzel 'неправильное воззрение', представляющее собой дословный перевод тиб. lta log 'превратное воззрение'. Производное от него buruүu üjeltü / buruи üzeltü ‘имеющий неправильные воззрения’ выступает

\footnotetext{
8 В «Монгольско-русско-французском словаре» О. М. Ковалевского приводятся следующие значения: albin (тиб. btsan) - демон, являющийся по ночам в виде сверкающего огня [МРФС 1, 1844: 84]. eliy-e (тиб. ne le, 'gong po, pho 'gong) - 1. коршун, ястреб; 2. злой, неприязненный дух в виде птицы; леший, черт [МРФС 1, 1844: 206], simnus (тиб. bdud) - недоброжелательный дух, нечистый дух, бес, представитель материи [МРФС 2, 1846: 1505], čidkür (тиб. 'gong po, pho 'gong, 'dre) — дьявол, черт, злой дух, леший [МРФС 3, 1849: 2159], külčin (тиб. 'gong po) - безобразный демон, как привидение, стращающий человека [МРФС 3, 1849: 2607].

${ }^{9}$ См. первое значение монг. eliy-e коршун'.

${ }^{10}$ Интересно отметить, что, согласно некоторым из проанализированных Ч. Боудэном источников, в насылании болезней элээ выступают помощниками онгонов [Bawden 1961: 242].

11 Этот термин встречается в переводе «Сутры о мудрости и глупости», выполненном Тойн-гуши в период 1578-1612 гг. [Kollmar-Paulenz 2012: 99]. См. разделение современных калмыцких «посвященных» на «имеющих покровителей белой стороны» (калм. цаһан Үзгин сәкүстә) и «имеющих покровителей черной стороны» (калм. хар үзгин сәкүстә) [Бакаева 2003: 290].
} 


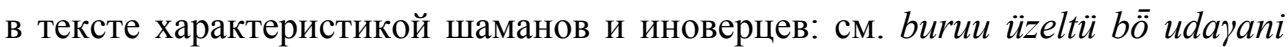
'шаманов и шаманок, имеющих неправильные воззрения', Padma Sambhaba baqši buruu üzelteni mou iröi belgeši erkedēn oroulji 'учитель Падмасамбхава, подчинив имеющих неправильные воззрения и плохие предзнаменования'

Эпитет xara 'черный’ в названии сочинения «Burxan baqšiyin nom xara šidi orošiboi» не может относиться к шаманизму, поскольку указывается прямая связь этой магии с учением Будды. В данном случае мы переводим xara как 'мирской', подразумевая, что это сочинение относится не к догматическому буддизму, а к народной религии, в которой буддийские концепции смешались с более ранними верованиями монгольских народов. Несомненным свидетельством влияния шаманистского культа является упоминаемая в тексте дихотомия «потрескавшаяся мать-земля» (ойр. kürösütü ötögün eke) — «синее небо» (ойр. kükü oqtorvui) [Heissig 1976: 436].

Маркировка обрядовых текстов как qara / xara 'черный' встречается также среди сочинений по скапулимантии (гаданию по бараньей лопатке) [Bawden 1961: 254]. Как правило, такие тексты содержат описание «черных» ритуалов, противопоставляющихся «белым» ${ }^{12}$, а в некоторых случаях предшествующих им. Ч. Боудэн описывает одно из таких сочинений «Qara čayan ugiyal: dkar nag khrus bzhugs so» ('Черное и белое омовение'), путем начитывания которого и выполнения соответствующих ритуалов смываются скверны и вредоносные влияния злых духов на заказчика ритуала [Bawden 1961: 256]. Ритуал, в котором присутствуют элементы «черного» омовения, представлен и в рассматриваемом тексте: в роли сосуда, в который помещаются все вредоносные влияния, выступает рог черной коровы. Он омывается черной водой, связывается многоцветной веревкой и таким образом запечатывается. После этого голова человека, над которым проводится обряд, покрывается куском черного сукна, чтобы избавить того от последствий плохих предзнаменований.

Что касается происхождения текста, В. Хайссиг, рассматривая монгольские версии, пишет, что тибетский оригинал среди канонических сочинений Ганджура и Данджура им не обнаружен, однако указывает, что фрагмент рассматриваемого текста встречается в «Дхарани Белозонтичной Тары», вошедшей в состав издания «Сундуя» 1729 г. [Heissig 1976: 435-436], что может указывать на компилятивный характер этого сочинения.

\section{Заключение}

Ойратский рукописный текст «Burxan baqšiyin nom xara šidi orošiboi» является списком сочинения, широко представленного в письменной традиции монгольских народов. Самые ранние монгольские списки обнаруживаются в коллекциях монастыря Олон-сюмэ и местности Харбухын Балгас, датируемых началом XVII в. Текст относится к обрядовой литературе, в которой наряду с буддийскими идеями представлены и более ранние верования монгольских народов. Получив буддийское оформление (зачин и концовка, санскритские дхарани), это сочинение содержит также элементы оригинальной монгольской мантической системы и народной магии.

Рассматриваемый текст представляет собой перечисление неблагоприятных предзнаменований, сопровождаемое просьбами нейтрализовать их и $\partial x a-$

\footnotetext{
${ }^{12}$ Можно предположить, что их происхождение связано с делением на белое и черное шаманство.
} 
рани, усиливающими эффект. Интерес представляет описание ритуала, вероятно, сопровождавшего чтение текста, с использованием рога черной коровы и отреза черного сукна. Этот ритуал может относиться к «черным» ритуалам народной религии, основное назначение которых заключалось в подавлении вредоносных влияний, и вся используемая атрибутика должна была быть черного цвета ${ }^{13}$.

Большая часть упоминаемых в тексте примет, связанных с животными и птицами, продолжает свое бытование в культуре монгольских народов (см.: [Душан 2016; Борджанова 2007; Хангалов 2004; Эрдэнэболд 2012]). Анализ текста показывает, что к неблагоприятным знакам относятся также природные явления (молния, гром, ураган), плохие помыслы, злословие окружающих, неблагоприятствования харш, связанные с временем, пространством, планетами и звездами, вредоносные влияния различных демонических существ и различные болезни. Изучение подобных обрядовых текстов позволит в дальнейшем расширить наши знания по мантическим практикам и верованиям монгольских народов и определить роль тибетской традиции в формировании корпуса этих текстов.

\section{Источники}

XS 2011 - Burxan baqsiyin nom xara šidi orošiboi ('Мирская магия учения Будды') [электронный ресурс] // Tod Nomin Gerel Collection. Digital Library for International Research Archive. Item \#11382. URL: http://www.dlir.org/archive/items/show/11382 (дата обращения: 15.01.2020).

\section{Литература}

Бакаева 2003 - Бакаева Э. П. Добуддийские верования калмыков. Элиста: АПП «Джангар», 2003. 358 с.

Бакаева 2009 - Бакаева Э. П. Сакральные коды культуры калмыков. Элиста: ИКИАТ, 2009. $159 \mathrm{c}$.

Банзаров 1891 - Черная вера или шаманство у монголов и другие статьи Дорджи Банзарова / под ред. Г. Н. Потанина. СПб: Тип. Имп. Акад. наук, 1891. 128 с.

Борджанова 2007 - Борджанова Т. Г. Обрядовая поэзия калмыков (система жанров, поэтика). Элиста: Калм. кн. изд-во, 2007. 592 с.

Душан 2016 - Душан У. Избранные труды / сост. В. В. Батыров, Т. И. Шараева. Элиста: КИГИ РАН, 2016. 376 с.

Митруев 2019 - Митруев Б. Л. Об ойратской рукописи «Зерцало менге» из Национального музея имени Алдан Маадыр Республики Тыва // Монголоведение. 2019. № 18(3). C. 508-518. DOI: 10.22162/2500-1523-2019-3-508-518

МРФС 1844-1849 - Монгольско-русско-французский словарь / сост. О. Ковалевский. Т. 1-3. Казань: Университ. тип., 1844-1849. 2690 с.

Позднеев 1993 - Позднеев А. М. Очерки быта буддийских монастырей и буддийского духовенства в Монголии в связи с отношением сего последнего к народу. Репринтное изд. Элиста: Калм. кн. изд-во, 1993. 512 с.

Хангалов $2004-$ Хангалов М. Н. Собрание сочинений в 3 т. Т. ІІІ / под ред. Г. Н. Румянцева. Улан-Удэ: Изд-во ОАО «Республиканская типография», 2004. 312 с.

Эрдэнэболд 2012 - Эрдэнэболд Л. Традиционные верования ойрат-монголов (конец XIX - начало XX в.) / пер. на рус. Ганбат Нямдаг, С. Б. Миягашева, Ж. Б. Бадагарова. Улан-Удэ: Изд-во БНЦ СО РАН, 2012. 196 с.

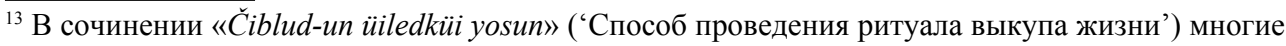
атрибуты, необходимые для выполнения ритуала, должны иметь черный цвет: черная земля (монг. qara sirui), фигурка эрлика черного вида (монг. qara dürüs-tü erlig), черная подстилка (монг. qara debisker), черные цветы (монг. qara čičig), черные злаки (монг. qara tariyan) [Bawden 1962: 170].
} 
Bawden 1961 - Bawden Ch. The Supernatural Element in Sickness and Death According to Mongol Tradition. Part I // Asia Major. Vol. 8. 1961. P. 215-257.

Bawden 1962 - Bawden Ch. The Supernatural Element in Sickness and Death According to Mongol Tradition. Part II // Asia Major. Vol. 9. 1962. P. 153-178.

Bawden 1994 - Bawden R. Charles. Confronting the Supernatural: Mongolian Traditional Ways and Means. Collected Papers. Wiesbaden: Harrassowitz Verlag, 1994. 273 p.

Chiodo 2009 - Chiodo E. The Mongolian Manuscripts on Birch Bark from Xarbuxyn Balgas in the Collection of the Mongolian Academy of Sciences. Part 2. Wiesbaden: Harrassowitz Verlag, 2009. 338 p.

Heissig 1976 - Heissig W. Die Mongolischen Handschriften-Reste aus Olon süme, Innere Mongolei (16.-17. Jhdt). Wiesbaden: Otto Harrassowitz, 1976. $633 \mathrm{~s}$.

Kollmar-Paulenz 2012 - Kollmar-Paulenz K. The Invention of "Shamanism" in $18^{\text {th }}$ century Mongolian Elite Discourse // Rocznik Orientalistyczny. T. LXV. Z. 1. 2012. S. 90-106.

\section{Sources}

[Burxan baqsiyin nom xara šidi orošiboi: Ordinary Magic of Buddha's Teaching]. At: Digital Library for International Research Archive. Item \#11382. Available at: http://www. dlir.org/archive/items/show/11382 (accessed: January 15, 2020). (In Oir.)

\section{References}

[Black Faith, or Shamanism of the Mongols - and Other Articles by Dordzhi Banzarov]. G. N. Potanin (ed.). St. Petersburg: Imperial Academy of Sciences, 1891. 128 p. (In Russ.)

[Mongolian-Russian-French Dictionary]. O. Kovalevsky (comp.). Vols. 1-3. Kazan: Imperial Kazan University, 1844-1849. 2690 p. (In Mong., Russ. and Fr.)

Bakaeva E. P. [Pre-Buddhist Beliefs of the Kalmyks]. Elista: Dzhangar, 2003. 358 p. (In Russ.)

Bakaeva E. P. [Sacred Codes of Kalmyk Culture]. Elista: IKIAT, 2009. 159 p. (In Russ.)

Bawden Ch. The supernatural element in sickness and death according to Mongol tradition. Part I. Asia Major. 1961. Vol. 8. Pp. 215-257. (In Eng.)

Bawden Ch. The supernatural element in sickness and death according to Mongol tradition. Part II. Asia Major. 1962. Vol. 9. Pp. 153-178. (In Eng.)

Bawden R. Ch. Confronting the Supernatural: Mongolian Traditional Ways and Means. Collected Papers. Wiesbaden: Harrassowitz Verlag, 1994. 273 p. (In Eng.)

Bordzhanova T. G. [Kalmyk Ceremonial Poetry: Genre System, Poetics]. Elista: Kalmyk Book Publ., 2007. 592 p. (In Russ.)

Chiodo E. The Mongolian Manuscripts on Birch Bark from Xarbuxyn Balgas in the Collection of the Mongolian Academy of Sciences. Part 2. Wiesbaden: Harrassowitz Verlag, 2009. 338 p. (In Eng.)

Dushan U. [Selected Works]. Batyrov V. V., Sharaeva T. I. (comps.). Elista: Kalmyk Humanities Research Institute of RAS, 2016. 376 p. (In Russ.)

Erdenebold L. [Traditional Beliefs of Oirat Mongols: Late $19^{\text {th }}-$ Early $20^{\text {th }}$ Centuries]. Ganbat Nyamdag, S. B. Miyagashev, Zh. B. Badagarov (transl.). Ulan-Ude: Buryat Scientific Center (Sib. Branch) of RAS, 2012. 196 p. (In Russ.)

Heissig W. [Mongolian Manuscripts from Olon Süme (Monastery), Inner Mongolia (16 ${ }^{\text {th }}-$ $17^{\text {th }}$ Centuries)]. Wiesbaden: Otto Harrassowitz, 1976. 633 p. (In Germ.)

Khangalov M. N. [Collected Works]. In 3 vols. Vol. III. G. N. Rumyantsev (ed.). Ulan-Ude: Respublikanskaya Tipografiya, 2004. 312 p. (In Russ.)

Kollmar-Paulenz K. The invention of 'shamanism' in $18^{\text {th }}$ century Mongolian elite discourse. Rocznik Orientalistyczny. 2012. Vol. LXV. No. 1. Pp. 90-106. (In Eng.)

Mitruev B. L. 'The Mirror of Menge': One Oirat Manuscripts from the Aldan Maadyr National Museum of the Tyva Republic Revisited. Mongolian Studies. 2019. No. 18(3). Pp. 508-518. (In Russ.) DOI: 10.22162/2500-1523-2019-3-508-518

Pozdneev A. M. [Essays on the Life of Buddhist Monasteries and Buddhist Clergy in Mongolia, in the Context of Their Relation to the People]. Reprint. Elista: Kalmyk Book Publ., 1993. 512 p. (In Russ.) 


\section{Приложение}

\section{Транслитерация и перевод ойратской рукописи «Burxan baqšiyin nom xara šidi orošiboi»}

\author{
Burxan baqšiyin nom xara šidi \\ orošiboi:: ${ }^{13}$ \\ [1b] namo buda-ya $\bar{a}^{14}$ \\ namo dharmaya \\ namo sanggaya: \\ blama-du mürgümüi: bi: blamayin \\ ünen zarliq-yēr čidküri darutuүai \\ burxan-du mürgümüi bi: burxani ünen \\ zarliq-yēr čidküri darutuүai \\ nom-du mürgümüi bi: nomiyin ünen \\ zarliq-yēr čidküri darutuүai
}

bursang xuvaraq-tu mürgümüi bi: bursang xuvaragiyin ünen zarliq-yēr čidküri daruturai::

xamuq burxan bodhi sadv-nar-tu [2a] nartu mürgümüi bi: xamuq burxan bodhi sadv-nariyin ünen zarliq-yēr čidküri darutuүai

küküütör xarši-du dedü yeke

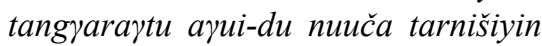
arbas tarni bügüdeyin ezeni buruu üzeltü ada todxor-noyoudiyin čuulyani

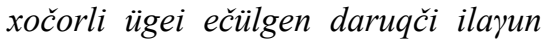
tögüsü\{q\}sen Očir paṇi-du maqtan mürgümüi::

küčün auүa zerge-bēr doura\{s\}xanxui yeke arbas [2b] tarnišiyin xan ene burxani yeke-dü mürgümüi:

öndör yeke uula-du yabuqči buүu eber-yēn orolduqsan mou iröge xariul:

köbčin ulušiyin noxoi deqši güiǰi xučaqsan mou iröge xariul:

\section{Мирская магия учения Будды}

Намо Буддхая.

Намо Дхармая.

Намо Сангхая.

Поклоняюсь Учителю. Да будут злые духи подавлены [силой] истинного слова Учителя!

Поклоняюсь Будде. Да будут злые духи подавлены [силой] истинного слова Будды!

Поклоняюсь Дхарме. Да будут злые духи подавлены [силой] истинного слова Дхармы!

Поклоняюсь Сангхе. Да будут злые духи подавлены [силой] истинного слова членов Сангхи!

Поклоняюсь всем буддам и бодхисаттвам. Да будут злые духи подавлены [силой] истинного слова всех будд и бодхисаттв!

Поклоняюсь и восхваляю Ваджрапани, Победоносного, усмирившего полностью полчища демонов, наделенных неправильными воззрениями, владыку всех тайных дхарани [Учения] тайной мантры, [пребывающего] во дворце синеватого цвета, в высшей пещере великих обетов.

Поклоняюсь великому Будде, царю тайных дхарани, усмиряющему силой и величием.

Отвратите плохое предзнаменование того, что олени, бродящие на вершине горы, сцепляются рогами.

Отвратите плохое предзнаменование того, что собаки всего селения лают и забираются на крышу ${ }^{15}$.

\footnotetext{
${ }^{13}$ В транслитерации используются следующие условные знаки: в фигурных скобках \{\} приводятся межстрочные вставки в тексте; со знаком равенства в скобках [=] — правильное написание слова; удаленные в транслитерации слова вычеркнуты так же в рукописи.

${ }^{14}$ Текст, выделенный полужирным шрифтом, написан в рукописи синими чернилами.

${ }^{15}$ Букв. 'наверху'.
} 
xoyor geriyin xoron zoura xoyor eme xoblolčon kelelčekü mou iröyigi xariul:

gegēn ödör ünegen gineiči xučaqsan mou iröigi xariul:

tere yuun buu kemēbesü: külčin čidkür [3a] kümüni xara milān keji deledkeǰ ünegeni xuс̌u mou iröyigi xariul:

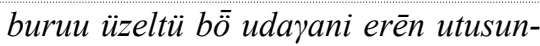
yēr deresü orōji čaqriq keqsen mou iröi-gi xariul:

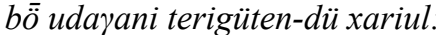

niskü šara šoboun odur (ödür) inekü mou iröi-gi xariul:

čār üker sürüqtēn bayiǰi ekerün möyirökü mou iröi-gi xariul:

aqtan morin güün-dü bayiqsan mou iröi-gi xariul:

ere morin iji- [3b] ldēn bayiǰi buruu xandun inčayaqsan mou iröi-gi xariul:

temen bā aduusun genete bolād xoyor burbi-yēn oroldulxu mou iröi-gi xariul:

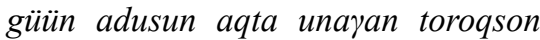
[=töröqsön] mou iröi-gi xariul ${ }^{18}$.

eme üker zourman tuүul töröqsön mou iröi-gi xariul:

ere kümüni tašāni sumuni mou iröigi xariul:
Отвратите плохое предзнаменование того, что две женщины ругаются, стоя между двумя домами.

Отвратите плохое предзнаменование того, что лисица скулит и лает посреди бела дня.

Отвратите плохое предзнаменование лая лисицы [с помощью того, что] демоны кулчины и чутгуры или человек взмахнут черной плетью.

Отвратите плохое предзнаменование того, что шаманы и шаманки, наделенные неправильными воззрениями, оборачивают разноцветным шнуром ковыль, делая кольцо.

Отвратите плохие предзнаменования шаманов, шаманок и прочих.

Отвратите плохое предзнаменование того, что летящий филин в дневное время смеется.

Отвратите плохое предзнаменование того, что близнецы в стаде коров и быков мычат $^{16}$.

Отвратите плохое предзнаменование того, что мерин находится среди кобылиц.

Отвратите плохое предзнаменование того, что кони, находясь среди своих, ржут, отвернувшись друг от друга. Отвратите плохое предзнаменование того, что верблюды и [другая] скотина внезапно ударяются ${ }^{17}$ пяточными сухожилиями.

Отвратите плохое предзнаменование того, что кобылица рожает жеребенка от мерина.

Отвратите плохое предзнаменование того, что у коровы случается выкидыш. Отвратите плохое предзнаменование стрелы, которую мужчина [носит] на боку.

\footnotetext{
16 Э. Чиодо переводит аналогичный фрагмент монгольского текста как «Отвратите плохое предзнаменование того, что кастрированный бык в стаде мычит, двигаясь взад-вперед».

${ }^{17}$ Букв. 'сцепляются'.

18 Э. Чиодо транслитерирует этот фрагмент монгольского текста как gegün aduүusun akiyad

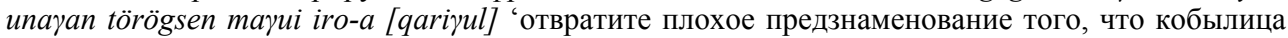
рожает увечного жеребенка' [Chiodo 2009: 184].
} 
blamnariyin küq duun-yēr geneqsen mou iröi-gi xariul:

bumbanariyin nomiyin sür [=sudar] [4a] orkiqsen mou iröi-gi xariul:

baqšiłna\}riyin čāsen-yēr yai sü örgüqsen mou iröi-gi xariul:

zoun nigen mou iröi-gi xariul:

ebečin taxul jai xarši čaru xariul:

xamuq ulušiyin xaraqsan geneqsen iröi-gi xariul

xoyor čidküriyin öšlön barilduqsan mou iröi-gi xariul:

öšötü kümüni öšiči xaraqsan mou iröigi xariul:

bi kümün čamai xariulxu busu bui:

küčün auүa zerge-bēr ye- [4b] kede Očir darayin arbas-yēr čamai xare\{lu\} um bi:

xamuq burxani ünen zarliq-yēr darutuyai

tenggeri burxani ünen zarliq-yēr daruturai

erte nögčiqsön Šakyamuni burxani zarliq ünen bui:

Padma Sambhaba baqši buruu üzelteni mou iröi belgeši erkedēn oroulǰi tangyaray šaqšabād xočorli ügei sapol zār xara ükeriyin eber čini dotor zayilum bi
Отвратите плохое предзнаменование того, что пение лам вызывает неприятие. Отвратите плохое предзнаменование того, что жрецы бонпо ${ }^{19}$ выбрасывают священные сутры Дхармы.

Отвратите плохое предзнаменование несчастья, призванного учителями.

\section{Отвратите сто одно плохое}

предзнаменование.

Отвратите неблагоприятствования

болезней и эпидемий.

Отвратите предзнаменование того, что все люди страдают и насылают проклятия.

Отвратите плохое предзнаменование того, что два демона, движимые чувством мести, нападают [на тебя].

Отвратите плохое предзнаменование проклятия, насланного мстительным человеком.

Разве я, человек, не [смогу] отвратить твое [влияние]?

Я отвращаю тебя с помощью заклинаниядхарани Ваджрадхары, наделенного великим могуществом.

Да будет подавлено [силой] истинного слова всех будд!

Да будет подавлено [силой] истинного слова будд и небожителей!

Это истинное учение прежде [жившего] Победоносного ${ }^{20}$ Шакьямуни.

[Подобно тому, как] учитель Падмасамбхава усмирил наделенных неправильными воззрениями и неблагими предзнаменованиями и связал их клятвами и [обетами] нравственного поведения, я изгоняю все в рог черной коровы.

\footnotetext{
19 Ч. Боудэн предполагает, что словом bombo (bumba) обозначался человек, занимавшийся магией и не обязательно имевший отношение к бону. В качестве синонимов исследователь

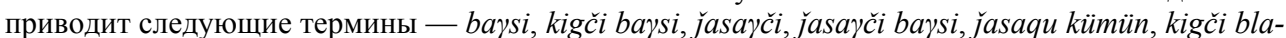
ma, tarniči, gelung [Bawden 1961: 251-252]. Слово bombo входит в состав парного термина bandi bombo (от тиб. ban bon) 'служители буддийского и бонского культа'.

${ }^{20}$ Возможно, неполная форма эпитета Будды - Победоносный (ойр. ilaju tegüs nöqčiqsön).
} 
xari daisun xamuq ada todxor čini dotoro xara usun-yēr zayilum bi xara ükeriyin [5a] eber külim bi. xari daisuni ada todxor-ri küčüüni čini bomoloči (?) alaq desen-yēr külim bi:

xaq xara ükeriyin uber [=eber]-yēr xabxaqlayam bi:

xari dayisuni xamuq xadou doqšin ada todxor mou iröi belgeši čini zamā ene balar xara örmögü-bēer tergiüni čini xabxaqlan bürküji tasulum bi:

da ka či ša om ka ra hum ka ra za ya om zam svā pād om zam svā pād hum pad \{pad\} hum bazar paṇi [5b] hum pad:

om yurban zoun jirin ada todxor xariul:

kükü oqtorqui-du nisči yabuqči šobouni mou iröi xariul:

kükü oqtoryui-yin tosoni xurāli giyisigeqsen xui salkini mou nü̈l iröi xariul:

xara kerē xamuq amitani dēre xašigiraji bulaldun barilduqsan mou nü̈l iröi xariul:

uuli šoboun xamuq ulusiyin ger dere dou yaruqson mou nüül iröi \{xariul\}

kürösütü ötögün ekedü yabuqči [6a] xamuq solongyo umayin xamuq xoroxoi kigēd ebüliyin čaqtu aliba ičiqsen amitan ülü üzüqdükü čaqtu üzeqsen mou nü̈̈l: iröi-gi xariul:

om zā miryā pad:

eke ečjigüyin geneqsen genēri xariul:

axa dougiyin mou sedkiqsen mou nüül iröi-gi xariul:

${ }^{21}$ Духи-покровители местности.

${ }^{22}$ Букв. 'над всеми живыми существами'.
Я смываю черной водой твоих врагов и вредоносные влияния.

Я связываю рог черной коровы.

Подчиняя негативную силу врагов и вредоносных влияний, я связываю цветной веревкой.

Закрываю рогом черной, как сажа, коровы.

Я покрываю твою голову куском темного черного сукна, чтобы отсечь на твоем пути вредоносные влияния врагов, хадов $^{21}$ и гневных духов и все неблагие предзнаменования.

дака чиша ом кара хум кара дзая ом дзам сва пад ом дзам сва пад хум пад пад хум бадзар пани хум пад.

\section{OM. Отвратите [влияние] трехсот} шестидесяти злых духов.

Отвратите плохое предзнаменование летящей в синем небе птицы.

Отвратите плохое, грешное

предзнаменование урагана, вздымающего столбы пыли до синего неба.

Отвратите плохое, грешное предзнаменование черных ворон, каркающих и дерущихся в небе $\mathrm{e}^{22}$. Отвратите плохое, грешное предзнаменование, когда сова ухает над домами всего селения.

Отвратите плохое, грешное предзнаменование, когда встречаются в период, [когда их не должно быть] видно, хорьки и [другие подобные животные этого вида], живущие внутри матери твердокорой земли, все насекомые из лона [земли] и все животные, впадающие зимой в спячку.

Ом дза мирья пад.

Отвратите страдания и беспокойство родителей.

Отвратите плохое грешное предзнаменование недобрых помыслов старших и младших братьев. 
xamuq amitan-ni xara sanaji xaraqsan mou nü̈̈l iröi-gi xariul:

mon [=mön] töüni xara tergüündüni xariul:

mou irö mou belge ebečin taxul xarši [6b] zobolong keqči ada todxor bügüdeyigi čāru xarilxu boltuүai::

blama la ya pad

ǰiliyin ülü bolxu:

xarši ba sarayin ülü bolxu xarši ba:

ödüriyin ülü bolxu xarši ba:

šöniyin ülü bolxu xarši ba:

üdeyin ülü bolxu xarši ba:

manayariyin ülü bolxu xarši ba:

dörbön zügiyin ülü bolxu xarši

dörbön zobkišiyin ülü bolxu xarši ba.

idēn ülü bolxu xaršsi ba:

garaq odun ülü bolxu xarši ba:

ga la ya pad ba ya ga la mu ran za ya: ši ta [7a] ya sa ma ra ya pad:

tenggeri duu yaruxuyin ayul-eče ibetügei:

čakilyani ayuul-eče ibetügei:

raliyin ayuul-eče ibētügei:

barši-yin ayuul-eče ibētügei:

kluyin ayuul-eče ibetügei

moyoyin ayuul-eče ibetügei: sakin soyirxo:

om ša ra da ka la ya pad

xāni-dun tomou akiqlan ebedküi ami bütēküi: genete xadxulaxui ebečini sakin soyirxo:

om ba da mu ye pad
Отвратите плохое грешное предзнаменование, когда все живые существа думают [о тебе] плохо и проклинают.

Обратите его на черноголовых.

Да будут все злые духи, насылающие плохие предзнаменования, знаки, болезни, эпидемии, неблагоприятствование и страдания, обращены вспять!

Лама лая пад.

[Да устранятся неблагоприятствования] года,

неблагоприятствования месяца, неблагоприятствования дня, неблагоприятствования ночи, неблагоприятствования полудня, неблагоприятствования следующего дня, неблагоприятствования четырех сторон света, неблагоприятствования четырех промежуточных направлений, неблагоприятствования, связанные с пищей, неблагоприятствования, связанные с планетами и звездами.

Галая пад бая гала муран дзая шитая самарая пад.

Да даруется защита от опасности грома!

Да даруется защита от опасности молнии!

Да даруется защита от опасности пожара! Да даруется защита от опасности [встречи с] хищниками ${ }^{23}$ !

Да даруется защита от опасности [встречи с] нагами!

Да даруется защита от опасности [встречи со] змеями! Соизвольте защитить!

Ом шара дака лая пад.

Соизвольте защитить от простуды, гриппа, затруднений с дыханием и резких болей!

Ом бада муйе пад.

${ }^{23}$ Букв. 'тиграми'. 
ekin [7b] ebečin nidün ebečin xamar ebečin aman ebečin zürken ebečin kümöi ebečin šüdün ebečin kebeli ebečin xajār ebečin čēji ebečin nurqun ebečin bel ebečin gedüsün ebečin šö̈üi ebečin:

törökü oron ebečin juyan ebečin: šilbi ebečin: yar ebečin köl ebečin: xoyitu xalyan ebečin ömönödü mör ebečin betegi ebečin gedesün kōkö: genete xadxulaxu untaxu tutum ebečin: bolxu [8a] idekü tutum xoron bolxu aman xaj̄ixu-yi nidü jirmülel ügei xurčan xaraxu yar-yēr ebčü-i deledkü köl-yēr yazar debsekü: mou iröi ügei boltuүai::

om a ka da ya svā ha:

nigen kümüni kelen aman aldas ügei xočoraxu boltuyai::

$\{2\}^{28}$ kümüni kele aman aldas ügei xоčoroxu bolturai::

$\{3\}$ kümüni kele aman aldas ügei xočoroxu bolturai

dörbön kümüni kelen aman aldas ügei xоčoroxu bolturai::

tabun [8b] kümüni kelen aman aldas ügei xočoroxu boltuүai::

zuryān kümüni kelen aman aldas ügei xоčoroxu bolturai::

\{7\} kümüni kelen aman aldas ügei xос̌оroxu bolturai::

naiman kümüni kelen aman aldas ügei xočoroxu bolturai::

\{9\} kümüni kelen aman aldas ügei xočoroxu bolturai::

$\{10\}$ kümüni kelen aman aldas ügei xос̌оroxu bolturai::

yisün yisün mou iröi belges čāru xarixu boltuүai::

ušan sarva yagša a ya ko ša maha zā za hum hum [9a] pad pad sva hā:

om pa čār čadi mahā ro hana hum pad:
Да исчезнут плохие предзнаменования болезней головы, глаз, носа, рта, сердца, горла, зубов, живота; [различных] аномалий; болезней груди, спины, поясницы, желудка, тазобедренных костей;

болезней матки ${ }^{24}$, бедра, голени, рук, ног, заднего прохода, мочеиспускательного канала ${ }^{25}$; опухоли печени; болезней желудка и груди, резких приступов нехватки дыхания во время сна; болезней, когда съеденная пища тебя отравляет; [невралгической] болезни, когда один уголок рта опущен; когда ты, не моргая, смотришь с пристрастием, бьешь руками в грудь и стучишь ногами ${ }^{26}$ !

Ом ака дая сваха.

Пусть злословие одного человека не будет иметь результата ${ }^{27}$ !

Пусть злословие двух людей не будет иметь результата!

Пусть злословие трех людей не будет иметь результата!

Пусть злословие четырех людей не будет иметь результата!

Пусть злословие пяти людей не будет иметь результата!

Пусть злословие шести людей не будет иметь результата!

Пусть злословие семи людей не будет иметь результата!

Пусть злословие восьми людей не будет иметь результата!

Пусть злословие девяти людей не будет иметь результата!

Пусть злословие десяти людей не будет иметь результата!

Да будет отвращено восемьдесят одно неблагое предзнаменование!

Ушан сарва якша айя коша маха дза дза хум хум пад пад сваха.

Ом падзар ияади маха рохана хум пад.

\footnotetext{
${ }^{24}$ Букв. 'места рождения'.

${ }^{25}$ Букв. 'переднего пути'.

${ }^{26}$ Возможно, описанная поза связана с ритуалом наложения проклятия.

${ }^{27}$ Букв. 'останутся без ошибок'.

28 В тех случаях, где в транслитерации числительные обозначены арабскими цифрами, в оригинальном тексте приводятся тибетские цифры.
} 
om pazār mahā ka la čiya čida biya na biya na ya ka hum hum pad pad svā hāa::

mou ebečin mou irö mou belges ügei bolxu bolturai:

om širi mahā ka la padma diq diq diya kuru širiya hum hum pad pad svā hā::

arban nasuni yai xarši čāru xaraxu [=xarixu boltuyai:

20 nasuni yai xarši $\{c \bar{a} a \overline{r u}\}$ xarixu bolturai:

30 nasuni yai xarši $\{$ čāru\} xarixu

[9b] döčin nasuni yai xarši čāru xarixu bolturai:

tabin nasuni yai xarši čāru xarixu bolturai:

60 nasuni yai xarši čāru xarixu bolturai:

dalan nasuni yai xarši $\{c ̌ a ̄ r u\}$ xarixu bolturai:

nayan nasuni yai xarši čāru xarixu boltu

yirin nasuni yai xarši čāru xarixu bolturai:

zoun nasuni yai xarši čāru xarixu bolturai:

zoun juiltü kelen amani yai xarši čāru xarixu boltuyai: urban xari- [10a]

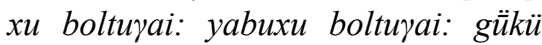
boltuyai tede bügüdegi sakin soyirxo::

ka la ro ba hum pad::

umaradu ulān albin čidküriyin ada ba:

doronodu okin elegiyin ada ba:
Ом падзар маха кала чийя чида бийяна бийяна яка хум хум пад пад сваха.

Да исчезнут плохие болезни, предзнаменования и знаки!

Ом шири маха кала падма дик дик дийя куру ширия хум хум пад пад сваха.

Да обратятся вспять неблагоприятствования десятилетнего возраста!

Да обратятся вспять неблагоприятствования двадцатилетнего возраста!

Да обратятся вспять неблагоприятствования тридцатилетнего возраста!

Да обратятся вспять неблагоприятствования сорокалетнего возраста!

Да обратятся вспять неблагоприятствования пятидесятилетнего возраста!

Да обратятся вспять неблагоприятствования шестидесятилетнего возраста! Да обратятся вспять неблагоприятствования семидесятилетнего возраста!

Да обратятся вспять неблагоприятствования восьмидесятилетнего возраста!

Да обратятся вспять неблагоприятствования девяностолетнего возраста!

Да обратятся вспять неблагоприятствования возраста ста лет!

Да обратятся вспять неблагоприятствования злословия в течение ста лет! Пусть они вернутся назад! Пусть уйдут! Пусть исчезнут! Соизвольте защитить от всех них! Кала роба хум пад.

От вредоносного влияния красных албинов и чутгуров северной стороны, от вредоносного влияния духов элээ ${ }^{29}$ восточной стороны,

29 Ч. Боудэн описывает этих духов как людей, которые после смерти стали привидениями [Bawden 1994: 70]. 
ömönödü tabun čidküriyin ba:

örönödü üker somnošiyin ada ba:

oqtoryuyin ča ān elegiyin ada ba

zabsariyin alaq elēgiyin ada ba

our-tu mou elēgiyin ada ba

tenggeri čidkuriyin ada ba

asuriyin ada ba:

kinariyin ada $b a$

garudiyin ada ba:

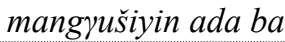

ödür [10b] yabuqčiyin ada ba:

šöni yabuqčiyin ada ba

rurban čaqtu yabuqčiyin ada ba

gerte moyoi züqlen kebteqčiyin ada ba

noxoi nu\{r\};u-bēn buruu xandan keb\{teq\} čiyin ada ba:

noxoi beye dēre yaran kebteqčiyin ada ba:

üker yazar maltan kebteqčiyin ada ba:

morini xamur-ēče čusu yaraqčiyin ada ba šên yadaqčiyin ada ba:

zürüken bolgin yabuqčiyin ada ba

yazariyin ada ba

usuni ada ba

kluyin ada ba:

naran garaq barijij ${ }^{32}$ xatun kümün-dü mou iröi geqčiyin [11a] ada ba:

saran garaq bariǰi xān kümün-dü mou irö geqčiyin ada ba: от [вредоносного влияния] пяти чутгуров южной стороны, от вредоносного влияния шимнусов западной стороны, [принимающих облик] коров,

от вредоносного влияния белых небесных духов элээ, от вредоносного влияния пестрых духов элээ промежуточного пространства, от вредоносного влияния плохих духов элээ воздуха,

от вредоносного влияния небесных чутгуров,

от вредоносного влияния асуров, от вредоносного влияния киннаров, от вредоносного влияния гаруд, от вредоносного влияния ракшасов, от вредоносного влияния идущего днем ${ }^{30}$, от вредоносного влияния идущего ночью ${ }^{31}$ от вредоносного влияния тех, кто перемещается в трех временах,

от вредоносного влияния змеи, лежащей по направлению к дому,

от вредоносного влияния собаки, лежащей, повернувшись спиной, от вредоносного влияния собаки, [пытающейся] забраться и улечься на человека, от вредоносного влияния коровы, которая ложится, взрыхлив [копытами] землю, от вредоносного влияния лошади, у которой носом идет кровь и которая не может помочиться

или страдает от учащенного сердцебиения, от вредоносного влияния земли, от вредоносного влияния воды, от вредоносного влияния нагов, от вредоносного влияния дурного предзнаменования о том, что солнечное затмение [опасно для] ханши, от вредоносного влияния дурного предзнаменования о том, что лунное затмение [опасно для] хана,

\footnotetext{
${ }^{30}$ Возможно, имеется в виду солнце.

${ }^{31}$ Возможно, имеется в виду луна.

${ }^{32}$ Буквальный перевод тиб. gza' 'dzin 'затмение'.
} 
odun čakilǰi mou irö geqčiyin ada ba:

tede bügüdiyin adas-eče sakin soyirxo

om yagša yagša hum pad

mou sedkin yabuqčid-eče zayiloutuүai:

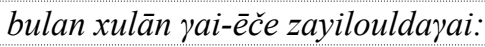

meseyin ayoul-ēče zayiloutuyai:

xaluxu mou ebečin-ēče zayiloutuүai:

mou üzel-ēče zayiloutuүai:

xamuq mou irö [11b] geqčid-ēče

zayiloutuyai

xortu moyoyin ayoul-ēče zayilouturai:

tenggeriyin tomor [=tömör] noxoyin

ayoul-ēče zayilouturai:

oqt oqtoryo gilbalyani ayoul-ēče

zayilouturai

yesun toloyōtu nayiman yeke raxuyin ayoul-ēče zayilouturai:

tede bügüdeyin ayoul-ēče sakin soyirxo:

om sum pā ṇi om sum pā ṇi hum gi ra ha na ba ya gir ha na ba ya hum a na

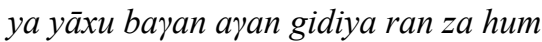
pad svä ha:

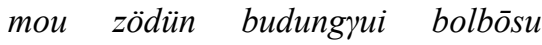
xariulxu bolturai:

yai xarši ügei bolxu boltuүai:

xanādun tomou ügei bolxu boltuүai:

möndür kiruu ügei bolxu boltuүai

ouladu yabubāsu xurdun arātan ülü xaldaxu bolturai::

usun-du yabubāsu xurdun matar zayasun klusud-un qād ülü xalaxu [=xaldaxu] bolturai:

beyedü mou ebečin xaldabasu ötör arilaxu bolturai::

\{be\}yedü e ebečin ilidun xabangxu namursun bōmo muxur xabudar čino yaran odun yaran xuluүuna yaran mou ebečin-ēče sakin soyirxo: ibēn sakituүai:: :

sarva ma ga lam:: от вредоносного влияния дурного

предзнаменования падающей звезды, От всех вредоносных влияний соизвольте защитить!

Ом якша якша хум пад.

Да минуется опасность плохих помыслов!

Да минуется опасность грабежа!

Да минуется опасность оружия ${ }^{33}$ !

Да минуются плохие болезни, [которые могут] пристать!

Да избегну я плохих воззрений!

Да минуется все, что относится к плохим предзнаменованиям!

Да минуется опасность ядовитых змей!

Да минуется опасность железных собак неба!

Да минуется опасность молний, [вспыхивающих] в небе!

Да минуется опасность восьми великих

Раху с девятью головами!

Соизвольте защитить от всех этих опасностей!

Ом сумбани сумбани хум гирахана бая гирахана бая хум аная йяхо бага аган гидия рандза хум пад сваха.

Если станут тяготить плохие сны, да будут они отвращены!

Да исчезнут бедствия!

Да исчезнут простудные заболевания!

Да не будет града и инея!

Если отправишься в горы, да не пристанут к тебе быстрые хищники!

Если окажешься в воде, да не пристанут к тебе быстрые крокодилы, рыбы и цари нагов!

Если к телу пристанет плохая болезнь, пусть она быстро отступит!

Соизвольте защитить от шестидесяти плохих болезней - чесотки, опухолей, лишая, нарывов, опухолей, волчанки, язв с точками, сифилиса. Да будет дарована защита!

Сарва мангалам.

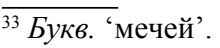

